\title{
Utilization of Sunflower Seed in Laying Hen Rations
}

\section{Author(s)}

Tsuzuki ET

Garcia ER de $\mathrm{M}^{2}$

Murakami $A E^{1}$

Sakamoto $\mathrm{Ml}^{1}$

Galli JR'

${ }^{1}$ Universidade Estadual de Maringá. Maringá, PR.

2 Universidade Estadual de Mato Grosso do Sul - Unidade de Aquidauana. Aquidauana, MS.

\section{Mail Address}

Elis Regina de Moraes Garcia Universidade Estadual de Mato Grosso do Sul Rodovia Aquidauana-Cera, km 12 Zona Rural

Aquidauana, MS

79.200-000

E-mail: ermgarcia@hotmail.com

\section{Keywords}

Egg quality, laying hens, performance, sunflower seed.

\section{ABSTRACT}

The objective of this trial was to evaluate the effect of sunflower seed inclusion (0, 1.4, 2.8, 4.2 and 5.6\%) in a laying hen diet containing corn, soybean meal, wheat meal and soybean oil as main ingredients on performance and egg quality. The evaluated variables were daily feed intake, average egg weight, feed conversion $\left(\mathrm{kg}^{\mathrm{kg}}{ }^{-1}\right.$ and $\left.\mathrm{kg} \cdot \mathrm{dz} \mathrm{z}^{-1}\right)$, eggshell percentage, yolk color and Haugh unit. One hundred and sixty 25 weekold Lohmann laying hens were used in a completely randomized design with five treatments and four replications of eight birds per experimental unit. Four periods of 28 days were evaluated during 112 days. The inclusion of sunflower seed in the diet had no effect on production parameters during the experimental period. Thus, can be concluded that sunflower seed might be used at concentrations up to $5.6 \%$ in laying hen diets without affecting performance and egg quality.

\section{INTRODUCTION}

Alternatives crops in Brazil, especially oilseeds, has been stimulated by important national cooperatives aiming to increase the production of oil to be used for human consumption. Among these crops, sunflower is an interesting option, since can be produced in different regions of the country.

Considering that poultry diets are usually corn-soybean meal based, it is frequently necessary to include vegetal oil to attend animal energy requirements, which increases feeding costs.

The use of oilseed in rations has stimulated the poultry industry because of its nutritional characteristics, such as protein and oil levels. Oilseeds might be considered an alternative to poultry breeders, since feeding corresponds to $70 \%$ of the total production cost.

Sunflower seed should be considered rich in energy, since it has from 3,691 to 5,004 kcal of ME. $\mathrm{kg}^{-1}$ and from 19.9 to $43.4 \%$ of ether extract (Daghir et al., 1980; Cheva-Isarakul \& Tangtaweewipat, 1990). Varieties with high oil concentration have increased levels of polyunsaturated fatty acids, mainly linoleic (Senkoylu \& Dale, 1999) and low levels of saturated fatty acids (Pelegrini, 1989).

Many studies have shown the benefits of polyunsaturated fatty acids on human health, especially in relation to heart problems and similarly important diseases (Leskanich \& Noble,1997). The authors suggested that the chemical composition of fatty acids in the yolk might be altered by manipulating the ingredients given to laying hens.

Most of the studies performed to evaluate the use of sunflower in hen feeding, sunflower meal have been used instead of whole seeds. Thus, little information exists concerning the use of sunflower seeds in diets for laying hens. 
The chemical composition of sunflower depends on the weather, variety, soil and how crops are grown (Karunajeewa et al., 1989; Senkoylu \& Dale, 1999). In this context, great variation in the chemical composition of sunflower meal has been observed due to the method for oil processing and extraction (Karunajeewa et al., 1989; Vieira et al., 1992).

Amino acid composition of sunflower seed is also variable, with levels of lysine and methionine ranging from $0.56 \%$ to $0.66 \%$ and from $0.33 \%$ to $0.50 \%$, respectively (Kashani \& Carlson, 1988). According to Vieira et al. (1992), lysine is the first limiting aminoacid in broiler sunflower meal-based diets. Thus, levels higher than $5 \%$ in diets require supplementation of lysine. However, Elliot (1998) emphasized that lysine supplementation of laying hen diets composed by sunflower meal does not seem to be so important when it is compared to broiler diets, because of the lower lysine requirements in laying hens.

This work evaluated different inclusion levels of sunflower seed $(0.0,1.4,2.8,4.2$ and $5.6 \%)$ in diets containing corn, soybean meal, wheat meal and vegetal oil as main ingredients on the performance and egg quality of commercial laying hens.

\section{MATERIAL AND METHODS}

The experiment was performed at Aviário Experimental of Fazenda Experimental de Iguatemi (Universidade Estadual de Maringá) and lasted 112 days (4 periods of 28 days).

One hundred and sixty Lohmann laying hens aging 25 weeks were used. They were housed into galvanized wire cages measuring $25 \times 40 \times 45 \mathrm{~cm}$ (2 birds/cage) in a conventional laying hen house with clay tile roof.

Through drinkers with running water were placed in the front of the cages and were washed daily. Individual wood feeders were located above to drinkers and ration was offered ad libitum twice a day (in the morning and in the afternoon). Birds were submitted 17 hours of light per day, from 5 am to $8 \mathrm{pm}$.

Experimental rations (Table 1) were iso-energetic, isoproteic, iso-calcic, iso-phosphoric and iso-aminoacidic for methionine + cystine and lysine. Formulations were according to the strain requirements and based on the chemical composition and energetic value of ingredients reported by Rostagno et al. (2000), except for the chemical composition of sunflower seed (Table 2). The inclusion levels of sunflower seed were 0.0, 1.4, 2.8, 4.2 and $5.6 \%$, which was used in diets instead corn, soybean meal, wheat meal, and vegetal oil.

\begin{tabular}{|c|c|c|c|c|c|}
\hline \multirow{2}{*}{ Ingredients (\%) } & \multicolumn{5}{|c|}{ Rations } \\
\hline & 1 & 2 & 3 & 4 & 5 \\
\hline Corn & 59.59 & 58.82 & 59.28 & 58.91 & 57.92 \\
\hline Soybean meal & 27.67 & 26.95 & 26.39 & 25.73 & 25.14 \\
\hline Wheat meal & 0.39 & 0.87 & 0.26 & 0.38 & 0.63 \\
\hline Sunflower seed & 0.00 & 1.40 & 2.80 & 4.20 & 5.60 \\
\hline Calcium & 7.77 & 7.76 & 7.75 & 7.74 & 7.95 \\
\hline Vegetal oil & 1.90 & 1.50 & 0.80 & 0.30 & 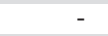 \\
\hline Bicalcium phosphate & 1.87 & 1.87 & 1.88 & 1.89 & 1.90 \\
\hline Sodium chloride & 0.42 & 0.42 & 0.42 & 0.42 & 0.42 \\
\hline Lysine, 78\% & 0.07 & 0.09 & 0.10 & 0.11 & 0.12 \\
\hline Mineral and vitamin mix & 0.20 & 0.20 & 0.20 & 0.20 & 0.20 \\
\hline DL - Methionine, 99\% & 0.11 & 0.11 & 0.11 & 0.11 & 0.11 \\
\hline BHT & 0.01 & 0.01 & 0.01 & 0.01 & 0.01 \\
\hline Total & 100.00 & 100.00 & 100.00 & 100.00 & 100.00 \\
\hline \multicolumn{6}{|c|}{ Calculated values } \\
\hline ME (kcal/kg) & 2850 & 2850 & 2850 & 2850 & 2850 \\
\hline Crude Protein (\%) & 18.00 & 18.00 & 18.00 & 18.00 & 18.00 \\
\hline Met + cys (\%) & 0.70 & 0.70 & 0.70 & 0.70 & 0.70 \\
\hline Lysine (\%) & 1.00 & 1.00 & 1.00 & 1.00 & 1.00 \\
\hline Calcium (\%) & 3.50 & 3.50 & 3.50 & 3.50 & 3.50 \\
\hline Available phosphorus (\%) & 0.45 & 0.45 & 0.45 & 0.45 & 0.45 \\
\hline Sodium (\%) & 0.18 & 0.18 & 0.18 & 0.18 & 0.18 \\
\hline Crude fiber (\%) & 2.89 & 3.09 & 3.23 & 3.41 & 3.59 \\
\hline \multicolumn{6}{|c|}{ 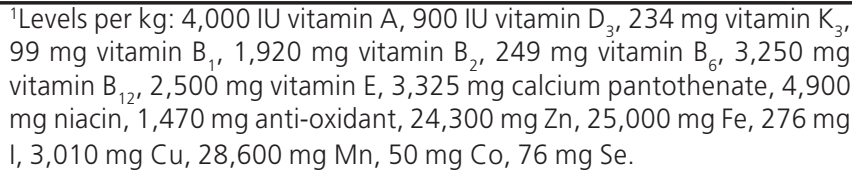 } \\
\hline
\end{tabular}

Table 2 - Chemical composition of sunflower seed (in original matter) ${ }^{1}$.

\begin{tabular}{|cc|}
\hline Nutrients & Values \\
\hline Dry matter (\%) & 93.10 \\
\hline Metabolizable energy (kcal/kg) & 4,925 \\
Crude protein (\%) & 21.75 \\
Calcium (\%) & 0.33 \\
\hline Total phosphorus (\%) & 0.72 \\
\hline Ether extract (\%) & 39.89 \\
\hline Crude fiber (\%) & 15.51 \\
\hline
\end{tabular}

1 - Analyzed by Laboratório de Análises de Alimentos - DZO/ UEM.

Laying hens were distributed in a completely randomized experimental design with 5 treatments and 4 replications of 8 birds per experimental unit.

Feed intake, production and weight of eggs, feed conversion $\left(\mathrm{kg} \cdot \mathrm{kg}^{-1}\right.$ and $\left.\mathrm{kg} \cdot \mathrm{dz}^{-1}\right)$ and internal and external quality of eggs were evaluated every each 28 days.

Three eggs per replication were used in the last five days of each cycle to evaluate eggshell, yolk color and albumen height. First, eggs were identified and broken to determine eggshell percentage. Shells were then 
washed, dried at room temperature for 48 hours and weighed in digital analytical scale (A500 Marte ${ }^{\circledR}$ ). Eggshell weight was expressed as a percentage of egg weight.

Yolk color was evaluated with a colorimetric fan (ROCHE ${ }^{\circledR}$ ) and colors were scored according to their intensity. Albumen height (in Haugh units) was measured with a micrometer (AMES - S $-6428^{\circledR}$ ) placed next to yolk and it was related to egg weight (g).

Egg weight, laying percentage, feed conversion $\left(\mathrm{kg} \cdot \mathrm{kg}^{-1}\right.$ and $\left.\mathrm{kg} \cdot \mathrm{dz}^{-1}\right)$, feed intake $\left(\mathrm{g} \cdot \mathrm{bird}^{-1} \cdot\right.$ day $\left.^{-1}\right)$, eggshell percentage and variables related to internal quality of eggs (yolk color and Haugh unit) were submitted to analysis of variance, considering inclusion levels of sunflower seed as independent variable. Data were analyzed according to the following model:

$$
Y_{i j}=m+N_{i}+e_{i j}
$$

Where:

$Y_{i j}=$ observed value of the variable studied in the $j$ diet with the $i$ level of sunflower seed inclusion;

$\mathrm{m}=$ general constant;

$\mathrm{N}_{\mathrm{i}}=$ effect of the ilevel of sunflower seed inclusion $(i=0.0 ; 1.4 ; 2.8 ; 4.2$ and $5.6 \%)$;

$\mathrm{e}_{\mathrm{ij}}=$ random error.

Means of treatments were compared by Dunnet's test at the level of significance of $5 \%$. Degrees of freedom of the levels of inclusion of sunflower seed were evaluated by polynomial analysis.

\section{RESULTS AND DISCUSSION}

The data of hen performance and egg quality are shown in Table 3. Regression analysis showed no effect $(p>0.05)$ of sunflower inclusion levels on the studied variables.

Increasing inclusion levels of sunflower seed did not affect ( $p>0.05$ ) daily feed intake and feed conversion $\left(\mathrm{kg} \cdot \mathrm{kg}^{-1}\right.$ and $\left.\mathrm{kg} \cdot \mathrm{dz}^{-1}\right)$, contrary to Karunajeewa et al. (1989) who reported that birds fed diets with sunflower seed had higher feed intake without affecting feed conversion $\left(\mathrm{kg} \cdot \mathrm{dz} \mathrm{z}^{-1}\right)$. The increase in feed consumption was attributed to the higher fiber level of rations containing sunflower seed (Karunajeewa et al., 1989).

According to Vieira et al. (1992), diets with high fiber contents have lower energetic value and reduce passage rate through the gastrointestinal tract and stimulate intake as a means to maintain a constant caloric intake.
Table 3 - Egg quality and performance of laying hens fed diets with different levels of sunflower seed.

\begin{tabular}{|c|c|c|c|c|c|}
\hline \multirow[b]{2}{*}{ Variables } & \multicolumn{5}{|c|}{ Levels of sunflower seed (\%) } \\
\hline & 0.0 & 1.4 & 2.8 & 4.2 & 5.6 \\
\hline Daily intake (g) & $100.10^{1}$ & 99.59 & 96.82 & 99.94 & 103.11 \\
\hline Feed conversion $\left(\mathrm{kg}^{\left.-\mathrm{kg}^{-1}\right)}\right.$ & 1.635 & 1.659 & 1.678 & 1.690 & 1.706 \\
\hline Feed conversion $\left(\mathrm{kg} \cdot \mathrm{dz} \mathrm{z}^{-1}\right)$ & 1.229 & 1.277 & 1.244 & 1.250 & 1.296 \\
\hline Laying percentage (\%) & 96.13 & 92.89 & 93.48 & 95.45 & 94.79 \\
\hline Egq Weight (q) & 61.94 & 64.13 & 61.75 & 61.63 & 63.32 \\
\hline Shell percentage (\%) & 8.72 & 8.90 & 8.70 & 8.84 & 8.93 \\
\hline Yolk color ${ }^{2}$ & 6.95 & 6.95 & 6.92 & 6.78 & 6.90 \\
\hline Haugh unit & 93.57 & 91.39 & 94.61 & 93.79 & 93.79 \\
\hline
\end{tabular}
was done ( $p>0.05$ ) by Dunnet's test. 2.Score - colorimetric fan (ROCHE $\left.{ }^{\circledR}\right)$.

Uwayjan et al. (1983) reported that the inclusion of $30 \%$ of sunflower seed in diets did not affect feed

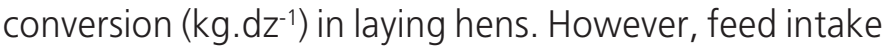
was reduced which might have been due to the increase in the energy content of the diet.

The findings obtained in this study were different from those reported by other authors (Rose et al., 1972; Deaton et al., 1979, Vieira et al., 1992) who observed that sunflower meal in laying hens diet increased feed intake, but feed conversion was poorer. The inclusion of sunflower seed reduces metabolizable energy (MEA $)$ of diets due to the high fiber content (Vieira et al., 1992). Nevertheless, this result was not seen in this experiment, probably because the levels of sunflower seed inclusion kept the levels of crude fiber within the range of bird requirements and not causing any physiological change.

There were no differences ( $p>0.05)$ among treatments considering laying percentage, egg weight and eggshell percentage. However, this might reflect the relationship between feed intake and feed conversion with production parameters.

Conversely to results found in this study, Uwayjan et al. (1983) observed reduced laying rate and increased egg weight when laying hens were fed with sunflower seed. On the other hand, heavier eggs were produced by hens fed with sunflower meal, whereas no differences in production parameters were seen between birds fed sunflower seeds with or without hulls (Karunajeewa et al., 1989).

Jiang et al. (1991) concluded that the addition of sunflower seed enriched with oleic and linoleic fatty acids in commercial hen diets had no effect on production and weight of eggs.

Rose et al. (1972) reported reduction in production and weight of eggs by hens fed diets in which all protein provided by soybean meal was substituted by sunflower meal protein. On the other hand, Deaton et al. (1979) 
found different results when 28 and 54 week-old laying hens were fed with a diet containing sunflower seed.

No effect ( $p>0.05$ ) of inclusion levels of sunflower seed was seen on yolk color and Haugh unit values. Similarly, the addition of $30 \%$ of sunflower seed in laying hen diets supplemented with $0.1 \%$ of lysine and $0.01 \%$ of methionine did not change the values of Haugh unit, although yolk color was less intense (Uwayjan et al., 1983), probably because of the reduced content of corn in rations.

Karunajeewa et al. (1989) observed that hens fed diets containing sunflower seed laid eggs with lower values of Haugh unit than hens fed with sunflower meal with or without supplementation of sunflower oil. It was especulated that sunflower seed might contain an anti-nutritional factor (low concentration) that could cause a reduction in albumen quality.

The results of this experiment were slightly different from those reported by other authors, since the evaluated levels of sunflower seed was not followed by changes in the levels of corn in diet and, consequently, not affecting yolk color.

\section{CONCLUSION}

The findings of this study suggest that sunflower seed can be included in commercial laying hens rations up to $5.6 \%$ without affecting performance or egg quality.

\section{REFERENCES}

Cheva-Isarakul B, Tangtaweewipat S. Effect of different levels of sunflower seed in broiler rations. Poultry Science 1990; 70:22842294.

Daghir NJ, Raz MA, Uwayjan M. Studies the utilization of full fat sunflower seed in broiler rations. Poultry Science 1980; 59:22732278.

Deaton JW, McNaughton JL, Burdick D. Hig-fiber sunflower meal as a replacement for soybean mal in layer diets. British Poultry Science 1979; 20:159-162.

Elliot MA. Aminoacid nutrition of commercial pullets and layers. In: Proceeding of Arkansas Nutrition Conference, Fayeheville, Arkansas, 1998. p.10-23.

Jiang Z, Ahn U, Ladner L, Sim JS. Influence of feeding full-fat and sunflower seeds on internal and sensory qualities of eggs. Poultry Science 1991: 71:378-382.
Karunajeewa H, Than SH, Abu-Serewa S. Sunflower seed meal, sunflower oil and full-fat sunflower seeds, hulls and kernels for laying hens. Animal Feed Science Technology 1989; 26:45-54.

Kashani A, Carlson CW. Use of sunflower seeds in grower diets for pullets and subsequent performance as affected by aureomycin and pelleting. Poultry Science 1988; 67:445-451.

Leskanich CO, Noble RC. Manipulation of the $n$-3 polyunsaturated fatty acid composition of avian eggs and meat. World's Poultry Science Journal 1997; 53:155-183.

Pelegrini B. Girassol: Uma planta solar que da América conquistou o mundo. São Paulo: Ícone. 1989. 117p.

Rose RJ, Coit RN, Sell JL. Sunflower seed meal as a replacement for soybean meal protein in laying hen rations. Poultry Science 1972; 51:960-967.

Rostagno HS, Albino LFT, Donzole JL, Gomes PC, Ferreira AS, Oliveira RF, Lopes DC. Tabelas brasileiras para aves e suínos: composição de alimentos e exigências nutricionais. Viçosa: UFV; 2000. $141 p$

Senkoylu N, Dale N. Sunflower meal in poultry diets: a review. World's Poultry Science Journal 1999; 55:153-174.

Uwayjan MG, Azar EJ, Daghir NJ. Sunflower seed in laying hen rations. Poultry Science 1983; 62:1247-1253.

Vieira SL, Penz Jr AM, Le Boute EM, Corteline J. A nutritional evaluation of a high fiber sunflower meal. Journal Applied Poultry Research 1992; 1:382-388. 